\title{
Principles of Modern Radiation Therapy Systems, Cyberknife \& Tomotherapy
}

\author{
Poorya Heydari* \\ Studied Biomedical Engineering, Cyberknife \& Radiotherapy Systems Researcher, Iran
}

Submission: December 18, 2017; Published: January 09, 2018

*Corresponding author: Poorya Heydari, Studied Biomedical Engineering, Cyberknife \& Radiotherapy Systems Researcher, Iran,

Email: heydari.bme.ihl@gmail.com

\section{Opinion}

In the treatment of diseases like cancer, reducing the difficulties of patients is so considerable.

Problems that can hurt the patient during the treatment such as, pain, stress, hard surgery, damaging healthy tissues around the target region, long course of treatment and etc. These kinds of problems make the patient feels bad along with his/her disease. By looking back at the past of cancer treatment system, it's clear that during the different decades, Researches and Scientifics have tried to reduce these problems and today, modern technologies like Cyberknife, Tomotherapy and Radixact have helped medical world to achieve this great goal.
Cyberknife by using high-tech systems for tracking and adjustment the target with submillimeter accuracy in order to protection healthy tissues around the target area, and exceptional maneuverability is the best choice to treat the tumors that are located near to the so critical and sensitive organs.

Tomotherapy by using Imaging Systems and Helical radiation with CT structure is capable of eliminating the large tumors.

In the end I want to point out Accuray company true motto, "Every Patient Deserves the best treatment available".

\begin{tabular}{l} 
Your next submission with Juniper Publishers \\
will reach you the below assets \\
- Quality Editorial service \\
- Swift Peer Review \\
- Reprints availability \\
- E-prints Service \\
- Manuscript Podcast for convenient understanding \\
- Global attainment for your research \\
- Manuscript accessibility in different formats \\
( Pdf, E-pub, Full Text, Audio) \\
- Unceasing customer service \\
Track the below URL for one-step submission \\
https://juniperpublishers.com/online-submission.php \\
\hline
\end{tabular}

